\title{
Human Immunodeficiency Virus and Malaria in a Representative Sample of Childbearing Women in Kigali, Rwanda
}

\author{
Susan Allen, Philippe Van de perre, Antoine Serufilira, \\ Philippe Lepage, Michel Carael, Andre DeClercq, \\ Jeff Tice, Dennis Black, Francois Nsengumuremyi, \\ John Ziegler, Jay Levy, and Stephen Hulley
}

\author{
Departments of Pathology and Medicine and Division of Clinical \\ Epidemiology (Department of Epidemiology and Biostatistics), and \\ Center for AIDS Prevention Studies, University of California, San \\ Francisco; Projet San Francisco and National AIDS Prevention Program \\ of Rwanda, Kigali; Global Programme on AIDS, World Health \\ Organization, Geneva. Switzerland
}

In 1986-1987 a consecutive sample of 3702 women presenting to prenatal and pediatric clinics at the only hospital in Kigali, Rwanda, was screened for human immunodeficiency virus (HIV) and malaria infection. The prevalence of HIV antibodies was $29 \%$, and that of malaria parasites was $9 \%$. HIV antibodies were more prevalent in women from the urban center than in those from the outskirts $(31 \%$ vs. $20 \%, P<.001)$, and malaria parasites showed the opposite prevalence pattern ( $8 \%$ vs. $15 \%, P<.001)$; after stratifying by location, there was no association between HIV and the presence or degree of malaria parasitemia. HIV prevalence was $45 \%$ in women who had received a blood transfusion between 1980-1985 (before screening of donated blood began), and $28 \%$ among the great majority $(94 \%)$ who had never been transfused. HIV prevalence was $44 \%$ in single mothers, $34 \%$ in women in common law unions, and $20 \%$ in those in legal marriages. These high rates of infection in the general population of Kigali highlight the need to develop effective programs for preventing further spread of sexually transmitted HIV.

Infection with the human immunodeficiency virus (HIV) is widespread in east and central Africa [1-15]. Although the infection has remained rare in most rural areas [16-18], it has become common in many cities. In Rwanda, a national HIV serosurvey in December 1986 found the prevalence of HIV antibodies to be $1 \%$ among rural inhabitants and $18 \%$ among those living in the cities $[19,20]$; among urban dwellers aged $26-40$ years, the prevalence was $30 \%$.

HIV and malaria share regions of endemicity in Africa, and there may be an association between the two infections. Early studies showed a relationship between antibodies to HIV and to Plasmodium falciparum [21,22], but a later report suggests that this may have been due to cross-reactivity and difficulty with interpretation of HIV-Western blot banding patterns [23]. Another study showed increased HIV infection rates in hospitalized children with a history of malaria, but this association was due to transfusions received for malaria-induced anemia $[24,25]$. Neither these nor other studies of the topic $[26,27]$ have resolved the question as to

Received 16 October 1990; revised 21 February 1991

Informed consent was obtained from women participating in the study, which was conducted in accordance with guidelines of the US Department of Health and Human Services and with the approval of the University of California, San Francisco, Committee on Human Research, and the government of Rwanda.

Grant support: Universitywide Task Force on AIDS, American Philosophical Society, and National Institutes of Health (AI-23980, MH-42459).

Reprints or correspondence: Dr. Susan Allen. 74 New Montgomery St., Suite 600, San Francisco, CA 94105.

The Journal of Infectious Diseases 1991;164:67-71

(C) 1991 by The University of Chicago. All rights reserved.

$0022-1899 / 91 / 6401-0010 \$ 01.00$ whether infection with HIV predisposes to more frequent, longer, or more severe malaria parasitemia.

We studied a representative sample of childbearing women recruited from prenatal and pediatric clinics in $\mathrm{Ki}$ gali, the capital city of Rwanda. This report analyzes the relationships among HIV antibodies and malaria parasitemia, history of transfusion, and demographic variables.

\section{Methods}

Sampling. Between October 1986 and March 1987, consecutive women aged 18 to 35 years and presenting to prenatal care or pediatric outpatient clinics at the Centre Hospitalier de Kigali were enrolled. This is the only community hospital in the city and is used by most Kigali women. There are good roads and buses in the city, and most of the women lived within $10 \mathrm{~km}$ of the hospital. The rate of refusal or incomplete data was $5 \%$, yielding a study sample of 3702 women who are reasonably representative of the population of 18- to 35-year-old childbearing women in Kigali.

Measurements. An interviewer-administered questionnaire was given in the local language (Kinyarwanda) to document name and address, marital status, spouse's profession, and obstetric and transfusion history. Blood $(10 \mathrm{ml})$ was taken for HIV serology and thick drop examination for trophozoites of $P$. falciparum. The remaining serum was frozen for later studies.

All sera were screened for HIV antibodies with a commercial ElA (Wellcome Diagnostics, Research Triangle Park, NC) in the Kigali laboratory of one of the authors (P.V.). A commercial Western blot (Du Pont, Wilmington, DE) was used as a confirmatory test. Western blots were considered positive if they had antibody to a core protein (p17, p25, p55) and antibody to at least one envelope protein (gp41, gp 120, gpl60). Specimens 
Table 1. Distribution of human immunodeficiency virus (HIV) infection in Rwandan women by age, marital status, and partner's profession.

\begin{tabular}{lrrr}
\hline & \multicolumn{2}{c}{$\begin{array}{c}\text { Distribution of } \\
\text { women }\end{array}$} & \% with \\
\cline { 2 - 3 } & \multicolumn{1}{c}{$n$} & $\%$ & HIV antibodies \\
\cline { 1 - 2 } Age (years) & & & \\
18-20 & 371 & 10 & 31 \\
$21-25$ & 1343 & 36 & 33 \\
$26-30$ & 1296 & 35 & 30 \\
$31-35$ & 692 & 19 & 19 \\
$\quad$ Total & 3702 & 100 & 29 \\
Marital status & & & \\
Legal marriage & 1639 & 44 & 21 \\
Common law union & 1708 & 46 & 33 \\
Single/divorced/ & & & \\
$\quad$ widowed/separated & 355 & 10 & 46 \\
$\quad$ Total & 3702 & 100 & 29 \\
Partner's profession* & & & \\
Farmer & 95 & 4 & 15 \\
Military & 118 & 5 & 21 \\
Unemployed & 30 & 1 & 27 \\
House worker & 125 & 5 & 28 \\
Civil servant & 527 & 20 & 29 \\
Private sector & 1686 & 65 & 30 \\
Other & 28 & 1 & - \\
$\quad$ Total & 2609 & 100 & 28 \\
\hline
\end{tabular}

NOTE. Values for HIV antibody prevalence by marital status and partner's profession are age-adjusted. Statistical significance was computed by $x^{2}$ for the age subgroup and by the Mantel Haenszel test for marital status and partner's profession subgroups. Differences among age and marital status subgroups in the percentage with antibodies were significant at $P<.001$ and among partner's profession subgroups at $P<.05$.

* Includes cohabiting partners of women in common law unions; 1093 whose partner's professions were not known were excluded. House workers include housekeepers, cooks, and gardeners. "Other" partners (includes students and entrepreneurs) could not be age-adjusted because some age categories were empty.

with only one band were considered negative. Western blot was positive in $95 \%$ of EIA-positive sera.

Blood smears were stained with Giemsa and evaluated by a single technician in the pathology laboratory of one of the authors (S.A.). Parasite density was graded as $1+, 2+$, or $3+$. All positives and an equal number of randomly selected negatives were reviewed blindly by a second technician; disparities were adjudicated by S.A. Thick drop results were available for $90 \%$ of the women screened; the remaining $10 \%$ were uninterpretable or lost during processing and transport.

Data entry and analysis. Data were entered on site and edited in response to range and logic checks done by the biostatistics staff at the Center for AIDS Prevention Studies in San Francisco. Proportions were age-adjusted to the sample age distribution. $\chi^{2}$ and $\chi^{2}$ for trend were used to compare proportions; the Mantel Haenszel $\chi^{2}$ test was used for age-adjusted proportions.

\section{Results}

Demographic distribution of HIV infection. The overall prevalence of HIV antibodies was $29 \%$. The prevalence clas- sified by demographic variables is given in table 1. Because the women were recruited from prenatal and pediatric clinics, they were sexually active and fertile. Most were 21-30 years old, and $90 \%$ had a cohabiting sexual partner; one-half of these were in legal marriages.

Women in legal marriages had a substantially lower ageadjusted prevalence of infection (21\%) than did those in common law unions (33\%), and both were less likely to be infected than those who were single, divorced, widowed, or separated $(46 \%)$. Women $>30$ years and those married to farmers and military men had relatively low prevalences of infection.

There was a strong inverse association between number of children and HIV infection, which remained when data were stratified by age and marital status (table 2).

Relationship of HIV infection to history of transfusion. A history of transfusion was reported by $225(6 \%)$ of the women; $40 \%$ of these had HIV antibodies (table 3). Over $99 \%$ had been transfused in Rwanda; most received blood at the Centre Hospitalier de Kigali. Analysis by date of transfusion showed that blood products were associated with high rates of infection (45\%) among those transfused in 1980-1985. Transfusion after 1985 (when screening in Rwanda was instituted by the Red Cross) was accompanied by attenuation of this risk, but the number of recent transfusions is too small for this decline to be statistically significant. Those who were never transfused had a prevalence of infection of $28 \%$.

Relationship of HIV infection to malaria. P. falciparum trophozoites were found in $9 \%$ of thick drops examined, decreasing over time from $12 \%$ in the first 10 weeks of screening (the rainy season) to $6 \%$ in the last 10 weeks (the dry season). The prevalence of malaria parasites decreased with age of the women (table 4). The age-adjusted prevalence of malaria in

Table 2. Distribution of human immunodeficiency virus (HIV) infection in Rwandan women by age, marital status, and number of children.

\begin{tabular}{|c|c|c|c|c|}
\hline \multirow[b]{2}{*}{$\begin{array}{c}\text { Age (years) } \\
\text { no. of children }\end{array}$} & \multicolumn{2}{|c|}{ Legal marriage } & \multicolumn{2}{|c|}{ Common law union } \\
\hline & No. & $\begin{array}{c}\% \text { with } \\
\text { HIV antibodies }\end{array}$ & No. & $\begin{array}{c}\% \text { with } \\
\text { HIV antibodies }\end{array}$ \\
\hline \multicolumn{5}{|l|}{$21-25$} \\
\hline $0-2$ & 342 & 26 & 479 & 41 \\
\hline $3-4$ & 133 & 17 & 221 & 30 \\
\hline$\geq 5$ & 24 & 8 & 21 & 33 \\
\hline Total & 499 & 23 & 721 & 37 \\
\hline \multicolumn{5}{|l|}{$26-30$} \\
\hline $0-2$ & 200 & 30 & 109 & 36 \\
\hline $3-4$ & 265 & 23 & 270 & 33 \\
\hline$\geq 5$ & 178 & 17 & 159 & 28 \\
\hline Total & 643 & 23 & 538 & 32 \\
\hline
\end{tabular}

NOTE. Results are for women aged 21-25 and 26-30 who cohabited with a male partner; numbers in other age categories were too small for analysis. Statistical significance of the differences among subgroups in the percentage was computed by $\chi^{2}$ for trend. $P<.01$ for all groups, except those $26-30$ years in common law unions for which $P=.16$. 
Table 3. Distribution of human immunodeficiency virus (HIV) infection in Rwandan women by history of blood transfusion.

\begin{tabular}{lrcc}
\hline & \multicolumn{2}{c}{$\begin{array}{c}\text { Distribution of } \\
\text { women }\end{array}$} & \\
\cline { 2 - 3 } $\begin{array}{c}\text { Transfusion } \\
\text { status }\end{array}$ & No. & $\%$ & \% with \\
\hline Transfused & 225 & 6.1 & 40 \\
Before 1980 & 39 & 1.0 & 22 \\
$1980-1985$ & 165 & 4.5 & 45 \\
$1986-1987$ & 21 & 0.6 & 30 \\
Never transfused & 3477 & 93.9 & 28 \\
$\quad$ Total & 3702 & 100 & 29 \\
\hline
\end{tabular}

NOTE. HIV antibody prevalences are age adjusted. The comparison between the proportion infected who reported ever being transfused (40\%) and the proportion infected who reported never being transfused $(28 \%)$ was statistically signifcant $(P<.001$ by Mantel Haenszel test). Among those transfused in 1986-1987. the proportion infected did not differ from the propottion infected who were transfused in $1980-1985(P=.34)$.

the outskirts of town (15\%) was twice the prevalence in the city center $(8 \%)(P<.001)$. This is the opposite of the pattern for HIV infection, which was more prevalent in the city center (where the age-adjusted prevalence was $31 \%$ ) than in the outskirts $(20 \%)(P<.001)$.

Stratification showed no relationship between presence of parasitemia and antibodies to HIV in the whole sample or in either residential area (table 4). Similarly, no relationship was found between degree of parasitemia and the age-adjusted prevalence of HIV infection (table 5).

\section{Discussion}

In this consecutive sample of 3702 women presenting to the prenatal and pediatric clinics at the Centre Hospitalier de

Table 4. Prevalence of malaria parasites in Rwandan women by age, residential area, and human immunodeficiency virus (HIV) infection.

\begin{tabular}{|c|c|c|c|}
\hline & No. & $\begin{array}{l}\text { \% thick-drop } \\
\text { positive }\end{array}$ & $P$ \\
\hline \multicolumn{4}{|l|}{ Age (years) } \\
\hline $18-20$ & 337 & 13 & \multirow{5}{*}{$<.01$} \\
\hline $21-25$ & 1183 & 10 & \\
\hline $26-30$ & 1188 & 9 & \\
\hline $31-35$ & 618 & 7 & \\
\hline Total & 3326 & 9 & \\
\hline \multicolumn{4}{|l|}{ Residential area } \\
\hline City center, HIV $^{+}$ & 828 & 8 & \multirow[b]{2}{*}{.99} \\
\hline $\mathrm{HIV}^{-}$ & 1864 & 8 & \\
\hline Total & 2692 & 8 & \multirow{4}{*}{.37} \\
\hline Outskirts. HIV ${ }^{+}$ & 127 & 17 & \\
\hline $\mathrm{HIV}^{-}$ & 507 & 14 & \\
\hline Total & 634 & 15 & \\
\hline
\end{tabular}

NOTE. Statistical significance of age-specific prevalences was computed by $x^{2}$ for trend. Values for malaria prevalence by residential area were age-adjusted; statistical significance of the differences in age-adjusted nrevalences between those with and without HIV antibodics was computed by Mantel Haenszel test.
Table 5. Prevalence of human immunodeficiency virus (HIV) infection in Rwandan women with different levels of malaria parasitemia.

\begin{tabular}{lrc}
\hline Thick drop result & No. & $\begin{array}{c}\text { \% with } \\
\text { HIV antibodies }\end{array}$ \\
\hline Negative & 3019 & 29 \\
Rare trophozoites & 100 & 26 \\
$1+$ & 142 & 34 \\
$2+$ or $3+$ & 61 & 30 \\
$\quad$ Total & 3326 & 29 \\
\hline
\end{tabular}

NOTE. Statistical significance of the differences in age-adjusted prevalences computed by Mantel Haenszel test was $P=.47$.

Kigali, and representative of childbearing women in Kigali, the prevalence of antibodies to HIV was $29 \%$. This percentage is similar to that found among urban women of the same age group in a national serosurvey conducted at about the same time using modified cluster sampling methodology $[19,20]$.

The cellular immune system is an important part of the defense against malaria [28-30], and an increased susceptibility to malaria among those infected with HIV would not be unexpected. Moreover, malaria infection might facilitate infection with HIV as the virus replicates more easily in antigenically stimulated lymphocytes [31]. The results of our cross-sectional study suggest that there is not an important relationship between infection with HIV and the presence or severity of parasitemia, and indicate that the epidemic of HIV is unlikely to increase carriage and transmission rates of malaria substantially. The data are also consistent with different routes of transmission of the two diseases, that is with lack of transmission of HIV by anopheles mosquitos [32].

Because most subjects with severe symptoms of malaria would not have been included in this relatively healthy sample, the results do not rule out the possibility that HIV-infected patients with malaria have a more severe clinical course. Furthermore, repeated infection with malaria may influence the natural history of disease among those infected with HIV. As examples of this latter type of parasite-virus interaction, malaria is believed to act as a cofactor for Epstein-Barr virus-associated Burkitt's lymphoma in Africa $[33,34]$ and strongyloides or filariae may be cofactors for HTLV-I-induced leukemia [35, 36]. Prospective studies are needed to determine whether repeated immunosuppression or stimulation due to parasite infection hastens progression of HIV disease.

As in other studies, younger women had a higher prevalence of HIV infection $[5,19,20]$. The women in the sample who cohabited with a male sex partner $(90 \%)$ were at significantly lower risk than single mothers. Among women with cohabiting partners, one-half were in common law unions, and prevalence among these su'jects was higher than among legal wives. This result, independent of age, suggests that 
common law unions are more often nonmonogamous. Women in legal marriages were at comparatively lower risk, but the prevalence of infection in this group was still noteworthy: At $20 \%$, it is the highest seroprevalence rate reported in a "low-risk group" from this part of Africa.

As previously noted in Rwanda [17], living outside the city was associated with a lower risk of HIV infection. We also found a tendency for women with husbands in the military to have lower infection rates, possibly because many recruits have recently moved to the city from the rural areas or because AIDS education and condoms are provided in the camps.

Several factors may be responsible for the higher risk of HIV infection found in each age group among women who had fewer children. Women infertile due to infection with other venereal disease would be likely to have a higher prevalence of HIV. However, infertility is uncommon among Rwandan women attending prenatal and pediatric clinics, and a more likely interpretation is that the number of children is an indirect measure of the duration or degree of monogamy of a sexual union. It is also possible (though we have no evidence for it) that there may be less sexual intercourse during pregnancy or that the women may be less susceptible to the infection when they are pregnant.

The transfusion findings show that being a recipient of blood contributed to the risk of HIV infection between 1980 and 1985 when seroprevalence in the population was high and blood donor screening for HIV was not yet available. However, transfusions during this period were reported by $<5 \%$ of the women, so this avenue for spread accounts for only a small fraction of the infection in Rwanda.

This study shows that the Red Cross blood screening campaign in Rwanda can only account for a relatively small number of HIV infections prevented. The high prevalence of infection even in the lowest risk groups of the general population of Kigali highlights the need to develop effective prevention programs for sexual transmission, the pathway believed responsible for the great majority of HIV infections in Rwanda.

\section{Acknowledgments}

We gratefully acknowledge the Rwandan staff of Projet San Francisco in Kigali (without whose expert and dedicated service this work could not have been completed), the Rwanda $\mathrm{Na}$ tional AIDS Program and National AIDS Commission, the Centre Hospitalier de Kigali, and the Rwandan Ministry of Health. We also thank the staff at the Center for AIDS Prevention Studies, particularly Rob DuWors.

\section{References}

1. Vandeperre P, Rouvroy D, Lepage P, et al. Acquired immune deficiency syndrome in Rwanda. Lancet 1984;2:62-5.
2. Vandeperre P, Carael M, Robert-Guroff M, et al. Female prostitutes: a risk group for infection with human $\mathrm{T}$ cell lymphotrophic virus type III. Lancet 1985;2:524-6.

3. Clumeck N, Robert-Guroff M, Vandeperre P, et al. Seroepidemiological studies of HTLV-III antibody prevalence among selected groups of heterosexual Africans. JAMA 1985:254:2599-602.

4. Melbye M, Njelesani EK, Bayley A, et al. Evidence for heterosexual transmission and clinical manifestations of human immunodeficiency virus infection and related conditions in Lusaka, Zambia. Lancet 1986;2:1113-5.

5. Mann J, Francis H, Quinn T, et al. HIV seroincidence in a hospital worker population in Kinshasa, Zaire. Ann Soc Belg Med Trop 1986;66:245-50.

6. Quinn T, Mann JM, Curran JW, Piot P. AIDS in Africa: an epidemiologic paradigm. Science 1986;234:955-63.

7. Carswell JW. HIV infection in healthy persons in Uganda. AIDS $1987 ; 1: 223-7$

8. Hudson C, Hennis A, Kataaha P, et al. Risk factors for the spread of AIDS in rural Africa: evidence from a comparative seroepidemiological survey of AIDS, hepatitis B and syphilis in southwestern Uganda. AIDS 1988:2:255-60.

9. Fleming AF. Seroepidemiology of human immunodeficiency viruses in Africa. Biomed Pharmacother 1988;42:309-20.

10. N'Galy B, Ryder R. Epidemiology of HIV infection in Africa. J AIDS 1988; 1:55I-8.

11. Carael M, Vandeperre P, Lepage P, et al. Human immunodeficiency virus transmission among heterosexual couples in central Africa. AIDS 1988:2:201-5.

12. Piot P, Plummer F, Mhalu F, Lamboray J, Chin J, Mann JM. AIDS: an international perspective. Science 1988;239:573.

13. Piot $\mathbf{P}$, Carael $\mathbf{M}$. Epidemiological and sociological aspects of HIV infection in developing countries. BMJ 1988;44:68-88.

14. Berkley S, Widy-Wirsky R, Okware SI, et al. Risk factors associated with HIV infection in Uganda. J Infect Dis 1989;160:22-30.

15. Clumeck N, Carael M, Rouvroy D. Heterosexual promiscuity among African patients with AIDS. Lancet 1989;2:182.

16. Nzilambi N, DeCock K, Forthal D, et al. The prevalence of infection with human immunodeficiency virus over a 10 year period in rural 7aire. N Engl J Med 1988;318:276-9.

17. Vandeperre P, LePolain B, Carael M. Nzaramba D, Zissis G, Butzler JP. HIV antibodies in a remote rural area in Rwanda, Central Africa: an analysis of potential risk factors for HIV seropositivity. AIDS 1987:1:213-5.

18. Schmutzhard E, Fuchs D, Hengster $P$, et al. Retroviral infections (HIV1, HIV-2, and HTLV-1) in rural northwestern Tanzania. Am J Epidemiol 1989;130:309-18.

19. Bugingo G, Ntilivamunda A, Nzaramba D. Etude sur la seropositivite liee a l'infection au virus de l'immundeficience humaine au Rwanda. Rev Med Rwandaise 1988;20:37-42.

20. Rwandan HIV seroprevalence study group. Nationwide community. based serological survey of HIV-1 and other human retrovirus infections in a central African country. Lancet 1989;1:941-3.

21. Biggar RJ, Gigase PL, Melbye M, et al. ELISA HTLV retrovirus antibody reactivity associated with malaria and immune complexes in healthy Africans. Lancet 1985:2:520-3.

22. Volsky DJ, Wu YT, Stevenson M. et al. Antibodies to HTLV-III/LAV in Venezuelan patients with acute malarial infections. $\mathrm{N}$ Engl $\mathrm{J}$ Med 1986:314:647-8.

23. Greenberg AE, Schable CA, Sulzer AJ, Collins WE, Nguyen-Dinh P. Evaluation of cross-reactivity between antibodies to plasmodium and HTLV-III/LAV. Lancet 1986;2:247-9.

24. Nguyen-Dinh P, Greenberg AE, Mann JM, et al. Absence of associa- 
tion between $P$ falciparum malaria and HIV infection in children in Kinshasa, Zaire. Bull World Health Organ 1987;65:607-13.

25. Greenberg A, Nguyen-Dinh P, Mann JM, et al. The association between malaria, blood transfusions, and HIV seropositivity in a pediatric population in Kinshasa, Zaire. JAMA 1988:259:545-9.

26. Simooya O, Mwendapole RM, Siziya S, Fleming A. Relation between falciparum malaria and HIV seropositivity in Ndola, Zambia. BMJ 1988;297:30-1.

27. Wabwire-Mangen F, ShiffCJ, Vlahov D, et al. Immunological effects of HIV-l infection on the humoral response to malaria in an African population. Am J Trop Med Hyg 1989:41:504-11.

28. Greenwood BM, Whittle HC, eds. Immunology of medicine in the tropics. London: Edward Arnold, 1981.

29. Allison AC, Eugui EM. A radical interpretation of immunity to malaria parasites. Lancet 1981;2:1431-3.

30. Chandra RK. Immunde responses in parasitic diseases: mechanisms. Rev Infect Dis 1982;4:756-62.
31. Margolick JB, Volkman DJ, Folks TM, Fauci AS. Amplification of HTLV-III/LAV infection by antigen-induced activation of T-cells and direct suppression by virus of lymphocyte blastogenic responses. J Immunol 1987;138:1719-23.

32. Do insects transmit AIDS? Washington, DC: Office of Technology Assessment, US Congress, staff paper I, September 1987.

33. Epstein MA. Burkitt's lymphoma: clues to the role of malaria. Nature 1984:312:398.

34. Whittle HC, Brown J, Marsh K, et al. T-cell control of Epstein-Bar virus-infected B-cells lost during $P$. falciparum malaria. Nature 1984:312:449.

35. Tajima K, Fujita K, Tsukidate $S$, et al. Seroepidemiological studies on the effects of filarial parasites in infestation of adult T-cell leukemia virus in the Goto Islands of Japan. Gann 1983;74:188-91.

36. Yamaguchi K, Matutes E, Catovsky D, Galton DAG, Nakada K, Takatsuki K. Strongyloides stercoralis as candidate co-factor for HTLVI induced leukaemogenesis. Lancet 1987;2:94-5. 